\title{
Survey some of the factors influencing ethical judgments of the earnings management
}

\author{
Dr. Mohammad Hossein Vadiei Nowghabi \\ Faculty of Economics and Business Administration \\ Ferdowsi University of Mashhad (FUM), Iran \\ Saleh Anbarani (Corresponding Author) \\ Faculty of Economics and Business Administration \\ Ferdowsi University of Mashhad (FUM), Iran \\ Email: sanbarani9@yahoo.com
}

Received: March 13, 2012 Accepted: April 23, 2012 DOI: 10.5296/ijafr.v2i1.1664

\begin{abstract}
Earnings management is using judgment in reporting financial results and in structuring transactions to either mislead some stakeholders about the underlying economic performance of the company or to influence contractual outcomes that depend on reported accounting numbers (Kaplan, 2001).

This study investigates the ethical perception of students concerning different earnings management scenarios. A questionnaire is used to measure the ethical perception of the respondents concerning 15 earnings management scenarios. The questionnaire is based on the questionnaire of Merchant (1994) and Fischer and Rosenzweig (1995).

Sample including Fields of accounting and non- accounting (management and economics) all the senior students' admission to universities public of Iran. The results of the 250 questionnaires indicate that: (1) There is a significant difference between knowledge ethical operating earnings management and accounting earnings management. (2) There is a significant difference between knowledge ethical earnings management that decrease earnings and earnings management that increase earnings.

(3) There is a significant difference between knowledge ethical earnings management that affect earnings on a quarterly basis than earnings management that affect earnings on a yearly basis.
\end{abstract}

Keywords: Earnings management, professional judgment, ethical perception 


\section{MInstitute ${ }^{\text {Mech }}$}

\section{Introduction}

The objective of financial statements is to provide information about the financial position, performance and changes in financial position of an enterprise that is useful to a wide range of users in making economic decisions (Gowthorpe, 2005). The literature discusses several groups of users of financial statements. These groups are investors, employees, lenders, suppliers, customers, governments and the last but not least the general public. All these groups are important, however priority is usually awarded to investors and their information needs because they provide risk capital to companies.

Therefore it is management's duty to provide timely and accurate information to all these groups about the company's financial status. Internal management reporting on either a weekly or monthly basis often requires the manager to exercise judgment. This judgment generally relates to issues surrounding cut off of either revenue or expenditure (Maher, 2008). Bitner (2002) indicates that the main motivator for earnings management is greed. Arnott (2003) even stresses that if investors cannot trust the numbers, the investment world may well price equities to offer not merely a risk premium but also a credibility premium. Merchant and Rockness (1994) even identifies earnings management and manipulation as the greatest threats to ethics in accounting The literature mentioned numerous definitions of earnings management.

Firstly, earnings management is using judgment in reporting financial results and in structuring transactions to either mislead some stakeholders about the underlying economic performance of the company or to influence contractual outcomes that depend on reported accounting numbers (Kaplan,2001).Secondly, Elias (2002) uses a definition from a former SEC chairman which states that earnings management is accounting hocus-pocus where flexibility in financial reporting is exploited by managers who are trying to meet earnings expectations. Thirdly, Fischer and Rosenzweig (1995), use a more case specific definitions of earnings management as actions by division managers which serve to increase or decrease current reported earnings of a divisions without a corresponding increase or decrease in the long-term economic profitability of that division.

Finally, Prior et all (2008) define earnings management as managers exercising their discretion over the accounting numbers.

This paper distinguishes between two types of earnings management: operating earnings management and accounting earnings management. Operating earnings management deals with altering operating decisions to affect cash flows and net income for a period such as easing credit terms to increase sales. Accounting earnings management deals with using the flexibility in accounting standards to alter earnings numbers (Merchant, 1989). Why do managers engage in earnings management?

Prior (2008) gives three important motives for earnings managements. First managers' motive is to influence short term prices, particularly around the time of certain types of corporate events, such as stock issues. Second motive, is that certain contracts create an 
incentive for managers to engage in earnings management with the purpose of boosting bonus awards. Thirdly, there are also regulatory motivations for earnings management. Managers of regulated sectors suffer acute pressure form antitrust authorities regarding price controls and market share. Such pressure stimulates earnings management practices as a stratagem to appear less profitable.

Lev (2003) gives two additional motives for managers to engage in earnings management. One motive is to weather out the storm that is to continue operations with adequate funding and customer/supplier support until better times come. Second motive to engage in earnings management is to satisfy contractual arrangements (debt covenants).

Earnings may be managed in many different ways, but they all boil down to two basic possibilities. One is to alter the numbers that are already in the financial records, via discretionary accruals and other adjustments, and the other is to create or structure real transactions for the purpose of altering the reported numbers. There are also two sorts of motivations for altering the financial reports through disclosure decisions. Management may either intend to influence stakeholders' beliefs and behavior or to influence how contracts are performed (Gaa, 2007)

The remainder of the journal is organized as follows: first, literature review which gives a comprehensive overview of the literature concerning earnings management, secondly, the hypotheses development, thirdly the research method, fourthly research results and finally the conclusion.

\section{Literature review}

\subsection{Consequences of earnings management}

It important to know how colleagues within internal labor markets respond when they believe fellow managers have engaged in earnings management. The study of Kaplan (2007) uses three between subjects independent variables to investigate the consequences of earnings management; (1) behavior of the target manager (earnings management versus no earnings management, (2) the nature of the organization's budgetary control system (flexible versus rigid) and (3) the target manager's work history (average versus very favorable). Furthermore the study includes three groups of dependent variables. First of all, causal attributions which measure whether the manager's disposition/character

and factors related to the situation and the organization contributed to the manager's action. Secondly, morality judgments which is a measure of the manager's morality perceived by others. Finally, managerial reputation effects which measure whether the action taken by the manager influences his reputation in negative or positive way. The main results indicate that when the target manager did not engage in earnings

management the mean attribution measure was positive. This means that internal factors are having a greater influence on the target manager's action than did the budgetary control 
system. The target manager engaging in earnings management were judged lower concerning morality than a target manager who did not engage in earnings management regardless of the budgetary control system. Furthermore, a favorable work history mitigates morality judgments associated with target managers who do engage in earnings management. Finally, the reputation effects are more strongly associated with morality judgments about the target manager than with causal attributions. In conclusion, managers engaging in earnings management were judged significantly less ethical than managers deciding to refrain and the rigid budgetary systems and an intense focus on obtaining financial targets can lead to dysfunctional behavior.

\subsection{Ethical judgments of earnings management}

The article of Kaplan (2001) examines individuals' ethically related judgments about managers engaging in earnings management activities and how the individuals' roles influence their judgments. Kaplan (2001) uses an experiment to investigate the ethical judgments of earnings management. Participants were assigned to three roles; shareholders role, the unknown managers role, which is the role were the individual does not know the target manager personally and the known manager role were the individual does know the target manager personally. Furthermore the participants received three different earnings management scenarios. The first scenario is the operating gain case, where the manager ordered his employees to defer all discretionary expenditures into the next accounting period. The second scenario is the accounting gain case, where the manager called the engagement partner to postpone an invoice for work that had been completed until next year. The third scenario is the accounting loss case, where the manager lowered current year earnings by needlessly increasing the reserve for obsolescence. The results show that individuals assigned to the role of shareholder do not appear to make differentiated ethically related judgments across the three different cases whereas individuals assigned to the role of manager do. Furthermore, individuals assigned to the role of manager judge the accounting based cases as more unethical than the operating gain case. In summary the results of the study show that particularly for accounting based approaches to earnings management activities, an individual's role in the reporting process is likely to influence the ethically related judgments one forms.

\subsection{Ethical decision making and ethical judgment}

When a manager recognizes that an ethical issue is present, the manager will make a judgment on the relative merits of the problem and the numerous alternative solutions, and proceed to develop intent to act in a particular manner. As mentioned in Schepers (2003), ethical judgment can be examined using a three dimensional construct. The three dimensions are moral equity, relativism and contractualism. First, moral equity dimension examines basic issues of right and wrong such as fairness, justice, and moral right or wrong. Second the relativistic dimension references the social and cultural perceptions of ethics. This perception 


\section{MInstitute Macrothink $_{\text {Int }}$}

International Journal of Accounting and Financial Reporting

ISSN 2162-3082

2012, Vol. 2, No. 1

would typically be the product of later training, as one becomes more familiar with tradition and social environment. Finally, the contractualism dimension examines individual perceptions regarding the tacit understandings between individuals or between the individual and society. In the moral equity dimension, what is judged as just or fair by one individual may be seen as less just or less fair by another. Furthermore, when looking at the relativism dimension, individuals from different cultures may judge the same event as more or less acceptable. Finally, individuals from the same or different cultures may have differing understandings of the implicit social contract underlying business exchange (Schepers, 2003).

Schepers (2003) also mentioned and defined the term Machiavellianism as the tendency of an individual to detach from consideration of ethics and perform actions that profit the self. All the above mentioned includes individual factors which influences a managers ethical decision making. Situational factors such as organizational constraints and economic issues are not included.

Thus it can be concluded that ethical decision making as well as ethical judgment differ between individuals and cultures. This is important in understanding managers' intent to engage in earnings management. This is even more important in companies with employees form different ethical and cultural origin.

\subsection{Financial reporting and ethical failure}

When accountants and auditors fail to provide investors with reliable information that is relevant to their capital allocation decisions, investors with stakes in the success of the economic system suffer (Staubus, 2005). In the essay of Staubus, he discusses the ethics failures of 3 main groups; corporate managers, auditors, and accounting standards setters. Firstly, the ethics failure of corporate managers is that auditors and board members are not fully independent of management. Instead, management controls them to some extent. Therefore, there is no independent control over management's reporting on its own performance. This sets a high probability for corporate reporting failures. Secondly, auditors typically do not have that independence in fact and appearance that auditing standards require. First, there is the unlimited social intercourse between auditors and client personnel. A second reason for lack of independence is the auditor's fear of losing the audit client. Finally, non audit services are critical to the financial success of an auditing firm that engages in fierce price competition on auditing engagements.

The main problem is that auditors have stronger incentives to please management than to serve the investing public. Finally, the standards setting blame for financial reporting failures should not be neglected. The FASB is subject to criticism for ethics failures. Staubus discusses three major complaints. The first complain is that the FASB predominantly focuses on investors as the primary group of financial reporting users. Secondly, the FASB has responded to management's and auditors' demand for bright lines between acceptable and unacceptable bending of accounting principles to achieve the reporting objectives of managers by promulgating standards consisting of detailed rules rather than principles. Finally, the FASB failure of narrowing the areas of difference among 
alternative acceptable accounting practices. In conclusion, corporate management is primary responsible for financial reporting failures and deficiencies but auditor and standards setting bodies must bear shares of the blame. All groups have responsibilities concerning the provision of reliable, timely and transparent financial reporting. Failures to meet those responsibilities are ethics failures (Staubus, 2005).

\subsection{Auditor independence and earnings management}

Auditor independence is defined as the probability that an auditor will report a discovered breach. The economic theory of auditor independence suggests that auditors' incentives to compromise their independence are related to client importance, the ratio of quasi rents specific to the client divided by all other quasi rents (Chung, 2003).

If an auditor has discovered a breach by the given client, she faces a choice of reporting or not reporting the breach. If she reports the breach, then she risks being fired by the client, in which case the entire client specific quasi rent stream will be forfeited. Alternatively, if the auditor refrains from reporting the breach, then she will retain the client, and therefore the client specific quasi rents. However, there is a risk of being detected either by analysts in the investment community or the press, by regulators, or ex post because of restatements by the client or worsening of the client's financial condition possibly leading to bankruptcy.

A wealth maximizing auditor will refrain from reporting the breach if the benefits outweigh the cost. Incentives to compromise independence should increase with the extent of client opportunities and incentives to manage earnings, and decrease with the strength of corporate governance and auditor expertise.

\subsection{Failing firms and earnings management}

Literature suggests that failing firms such as Enron and WorldCom may be motivated to engage in fraudulent financial reporting to conceal their distress. Managers of failing firms, optimistically expecting their firms' troubles to be temporary, are motivated to engage in income increasing earnings management to conceal the deteriorating financial conditions until they improve (Rosner, 2003).

Rosner (2003) article shows to important outcomes concerning failing firms. First of all failing firms are more likely to engage in material income increasing earnings manipulation than non failing firms. Secondly, Rosner finds that financial statements of firms that auditors perceive to be failing are more likely to reflect reversals of previous income increasing earnings manipulation than the financial statements of firms that auditors do not perceive to be failing.

Therefore it can be concluded that the article provides insight into the financial reporting behaviour of failing firms, which is potentially useful for all financial statement users. These firms do not show distress based on accrual data but show significant drops in cash flows. These firms try to hide their distress in non going concern years by material overstating their 
earning and later on their financial statements need a reversal of the overstatement in going concern years.

\subsection{Ethical judgments of earnings management}

The article of Kaplan (2001) examines individuals' ethically related judgments about managers engaging in earnings management activities and how the individuals' roles influence their judgments. Kaplan (2001) uses an experiment to investigate the ethical judgments of earnings management. Participants were assigned to three roles; shareholders role, the unknown managers role, which is the role were the individual does not know the target manager personally and the known manager role were the individual does know the target manager personally. Furthermore the participants received three different earnings management scenarios. The first scenario is the operating gain case, where the manager ordered his employees to defer all discretionary expenditures into the next accounting period. The second scenario is the accounting gain case, where the manager called the engagement partner to postpone an invoice for work that had been completed until next year. The third scenario is the accounting loss case, where the manager lowered current year earnings by needlessly increasing the reserve for obsolescence. The results show that individuals assigned to the role of shareholder do not appear to make differentiated ethically related judgments across the three different cases whereas individuals assigned to the role of manager do. Furthermore, individuals assigned to the role of manager judge the accounting based cases as more unethical than the operating gain case. In summary the results of the study show that particularly for accounting based approaches to earnings management activities, an individual's role in the reporting process is likely to influence the ethically related judgments one forms.

\subsection{Ethics of managing earnings}

Merchant (1994) investigates how people judge the acceptability of earnings management actions. These judgments depend on the type of action (accounting vs. operating manipulation), consistency with GAAP, the direction of the effect on earnings, materiality, the period of effect and the purpose in mind. Furthermore, they investigate whether moral judgments are consistent across different populations such as managers in different firms and personnel in different roles. The results indicate that people's ethical judgments were affected by the type of earnings management. The accounting manipulations were judged much more harshly than the operating manipulation. Secondly, it did not matter whether accounting manipulations were consistent with GAAP concerning people's acceptability judgments. Thirdly the direction of effect on earnings was not important. This means that actions which boosted earnings were not rated significantly different from those which boosted earnings were not rated significantly different from those which decreased earnings. Fourthly, acceptability judgments concerning materiality mattered. Larger earnings management actions were rated significantly less acceptable than the smaller immaterial actions. Fifthly, 
the period of effect also mattered. The year-end earnings manipulations were judged significantly less acceptable than quarterend earnings manipulation. Finally, the manager's purpose for engaging in earnings management was a concern. People judge the selfish action (bonus reward) more harshly as the earnings manipulation for the corporation's best long term interest.

The results also indicate that managers in different firms judge earnings management significantly more harshly than others. The firm which had a recent major fraud incident judged earnings management more harshly than the company which did not have a major fraud incident. Furthermore general managers were judging earnings management more harshly were internal auditors were significantly more liberal in their judgments.

\section{Hypotheses development}

In the introduction I mentioned several definitions of earnings management. The definition used in this study is by Kaplan (2001) and states that earnings management occurs when managers use judgment in financial reporting and in structuring transactions to alter financial reports either to mislead some stakeholders about the underlying economic performance of the company or to influence contractual outcomes that depend on reported accounting numbers.

As already mentioned before, earnings management occurs when managers use judgment in financial reporting and in structuring transactions to alter financial reports either to mislead some stakeholders about the underlying economic performance of the company or to influence contractual outcomes that depend on reported accounting numbers (Kaplan, 2001). Merchant (1994) makes a distinction between operating earnings management and accounting earnings management. Operating earnings management involves altering operating decisions, such as the decision to work overtime at year end or to send out more shipments in the current year. Accounting earnings management consists of using the options available in both accounting rules and the application of those rules.

Merchant's (1994) results indicate that people's ethical judgments were affected by the type of earnings management. The accounting manipulations were judged much more harshly than the operating manipulation. Elias (2002) found that accountants, academics and students judge operating earnings management more leniently than accounting earnings management. Kaplan (2001) found in his results that individuals assigned to the role of manager judge the accounting based cases as more unethical than the operating gain case. Consequently, I will hypothesize that students will judge operating earnings management less severe or more leniently than accounting earnings management.

H1: There is a significant differences between knowledge ethical operating earnings management and accounting earnings management.

The direction of effect is an important factor in determining whether earnings management is acceptable or not. Managers can use earnings management to boost earnings or to decrease earnings. Merchant (1994) and Fischer and Rosenzweig (1995) conclude in their results that the direction of effect is not important. The earnings management scenarios that boosted earnings were not rated significantly different from those which decreased earnings. 


\section{MlMacrothink}

International Journal of Accounting and Financial Reporting

ISSN 2162-3082

2012, Vol. 2, No. 1

Therefore, I hypothesize those students overall do not judge earnings management that decreases earnings differently from earnings management that increases earnings.

$\mathrm{H} 2$ : There is a significant difference between knowledge ethical earnings management that decrease earnings and earnings management that increase earnings.

Managers engaging in earnings management can affect earnings on a quarterly or yearly basis. Merchant (1994) and Fischer and Rosenzweig (1995) conclude in their results that the year-end action was judged significantly less acceptable that the quarter-end manipulation. Based on their findings, I hypothesize that students will judge earnings management that affects earnings on a quarterly basis as more ethical than earnings management that affect earnings on a yearly basis.

H3: There is a significant difference between knowledge ethical earnings management that affect earnings on a quarterly basis than earnings management that affect earnings on a yearly basis.

\section{Research method}

I will collect data through the use of a questionnaire. The questionnaire sends for students accounting and non-accounting fields of public universities across Iran. have been Question 3 to question 15 are based on the questionnaire used in the article by Merchant (1994) and Fischer and Rosenzweig (1995). The questions are slightly rewritten and reshuffled but in such a matter that it is still possible to compare the results. The questionnaire used in this study is the original questionnaire by Fischer and Rosenzweig that can be found in Journal of Business Ethics 14, 1995, pp.441-442. The questionnaire consists out of 15 questions which show several earnings management scenarios. The students were asked to evaluate each earnings management scenario. They will indicate their ethical perception concerning the earnings management practices on a scale of 1 to 5 . The meaning of the scale is as follow; $1=$ totally ethical, $2=$ ethical, $3=$ minor infraction, $4=$ unethical, $5=$ totally unethical.

\section{Research results}

The total number of questionnaires used in this study equals 250. As already mentioned before, the questionnaire consists out of 15 earnings management scenarios and 3 personal/demographic questions. To test hypothesis 4 , I needed to know the gender of the respondents (Figure 1). Total number of respondents was 250 including 104 males (41.6\%) and 146 females $(58.4 \%)$. It should be noted that frequency non-accounting students and accounting students is equally in the questionnaire.

To test the hypothes is The following procedure is do:

Descriptive statistics used to place on the distribution of data in frequency tables, charts and the The central and scattering parameters. However, because given that a five-choice questions and Likert methods have been developed, so to determine the normal distribution of 
variables used of test ANOVA and T Test.

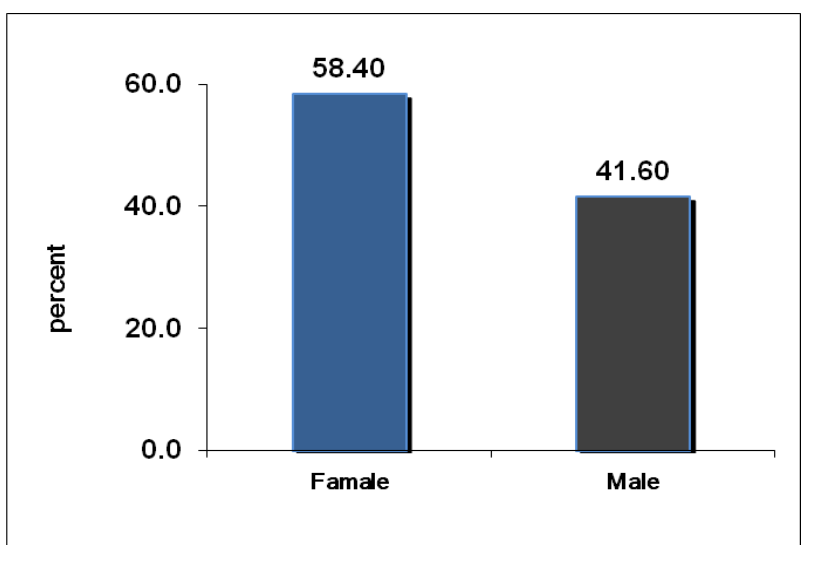

\begin{tabular}{|lcl|}
\hline \multicolumn{2}{|l|}{ Table 1-gender } \\
\hline $\begin{array}{l}\text { Valid } \\
\text { percent }\end{array}$ & frequency & gender \\
\hline 58.00 & 146 & Famale \\
\hline 42.00 & 104 & Male \\
\hline & & Missed \\
\hline 100.00 & 250 & total \\
\hline
\end{tabular}

Fioure 1-oender

also, The following, we Be provided The main formula for the tests of these hypothesis.

Variable AccountingEM $\frac{Q 3+Q 10+Q 11+Q 12+Q 13+Q 14+Q 15}{7}$

Variable OperatingEM $\frac{Q 4+Q 5+Q 6+Q 7+Q 8+Q 9}{6}$

Variable IncreaseEM $\frac{Q 3+Q 5+Q 6+Q 7+Q 8+Q 9+Q 10+Q 11+Q 12+Q 13}{10}$

Variable DecreaseEM $\frac{Q 4+Q 14+Q 15}{3}$

Hypothesis 6,7 will be tested using Analyze - Compare Means - Paired Samples T Test in SPSS. Doing of Details of the statistical in tests of these hypothesis present in the thesis. but we can present following The statistical tables:

Initially, Runs test and Kolmogorov test for accident data and normal is done: 


\begin{tabular}{|l|r|}
\hline \multicolumn{2}{|c|}{ Table2-Runs Test } \\
\hline Test Value $^{\mathrm{a}}$ & Mean \\
Cases < Test Value & 2.93 \\
Cases >= Test Value & 123 \\
Total Cases & 127 \\
Number of Runs & 250 \\
Z & 102 \\
Asymp. Sig. (2-tailed) & -3.039 \\
\hline
\end{tabular}

Table 3-One-Sample Kolmogoroff-Smirnoff Test

\begin{tabular}{|ll|r|}
\hline & & \multicolumn{1}{|c|}{ Mean } \\
\hline N & & 250 \\
Normal Parameters ${ }^{\mathrm{a}}$ & Mean & 2.8477 \\
& Std. Deviation & .82581 \\
& Extreme Absolute & .076 \\
Most & Positive & .076 \\
Differences $\quad$ Negative & -.069 \\
& & 1.197 \\
Kolmogoroff-Smirnoff Z & .114 \\
Asymp. Sig. (2-tailed) & &
\end{tabular}

Then the following statistical tests have been done:

\begin{tabular}{|rr|r|r|r|r|}
\hline & \multicolumn{1}{|c|}{ Mean } & $\mathrm{N}$ & \multicolumn{1}{c|}{ Std. Deviation } & Std. Error Mean \\
\hline Pair 1 & AccountingEM & 2.8029 & 250 & .86138 & .05448 \\
& & & & .82653 & .05227 \\
\hline
\end{tabular}

Table 5-Paired Samples Correlations

\begin{tabular}{|ll|r|r|r|}
\hline & \multicolumn{1}{|c|}{$\mathrm{N}$} & \multicolumn{1}{c|}{ Correlation } & \multicolumn{1}{c|}{ Sig. } \\
\hline Pair 1 AccountingEM \& OperatingEM & 250 & .836 & .000 \\
\hline
\end{tabular}

Table 6-Paired Samples Test

\begin{tabular}{|c|c|c|c|c|c|c|c|c|}
\hline & \multicolumn{5}{|c|}{ Paired Differences } & \multirow[b]{3}{*}{$\mathrm{t}$} & \multirow[b]{3}{*}{$d f$} & \multirow[b]{3}{*}{ Sig. (2-tailed) } \\
\hline & \multirow[b]{2}{*}{ Mean } & \multirow[b]{2}{*}{ Std. Deviation } & \multirow[b]{2}{*}{ Std. Error Mean } & \multicolumn{2}{|c|}{$\begin{array}{c}95 \% \text { Confidence Interval of } \\
\text { the Difference }\end{array}$} & & & \\
\hline & & & & Lower & Upper & & & \\
\hline $\begin{array}{c}\text { Pair } 1 \text { AccountingEM } \\
\text { OperatingEM }\end{array}$ & -.10514 & .48470 & .03066 & -.16552 & -.04477 & -3.430 & 249 & .001 \\
\hline
\end{tabular}

Therefore, We accept the first hypothesis:

There is a significant difference between knowledge ethical operating earnings management and accounting earnings management. 


\section{Al Macrothink \\ International Journal of Accounting and Financial Reporting

The following tables have been prepared to test the fifth hypothesis:

Table 7-Group Statistics

\begin{tabular}{|rr|r|r|r|r|}
\hline & \multicolumn{1}{|c|}{ Mean } & \multicolumn{1}{c|}{$\mathrm{N}$} & \multicolumn{1}{c|}{ Std. Deviation } & Std. Error Mean \\
\hline Pair 1 & Increase EM & 2.8096 & 250 & .81973 & .05184 \\
& & & & \\
& Decrease EM & 2.9907 & 250 & .96313 & .06091 \\
\hline
\end{tabular}

Table 8-Independent Samples Test

\begin{tabular}{|l|r|r|r|}
\hline & \multicolumn{1}{|c|}{$\mathrm{N}$} & \multicolumn{1}{c|}{ Correlation } & \multicolumn{1}{c|}{ Sig. } \\
\hline Pair 1 IncreaseEM \& DecreaseEM & 250 & .747 & .000 \\
\hline
\end{tabular}

Table 9-Paired Samples Test

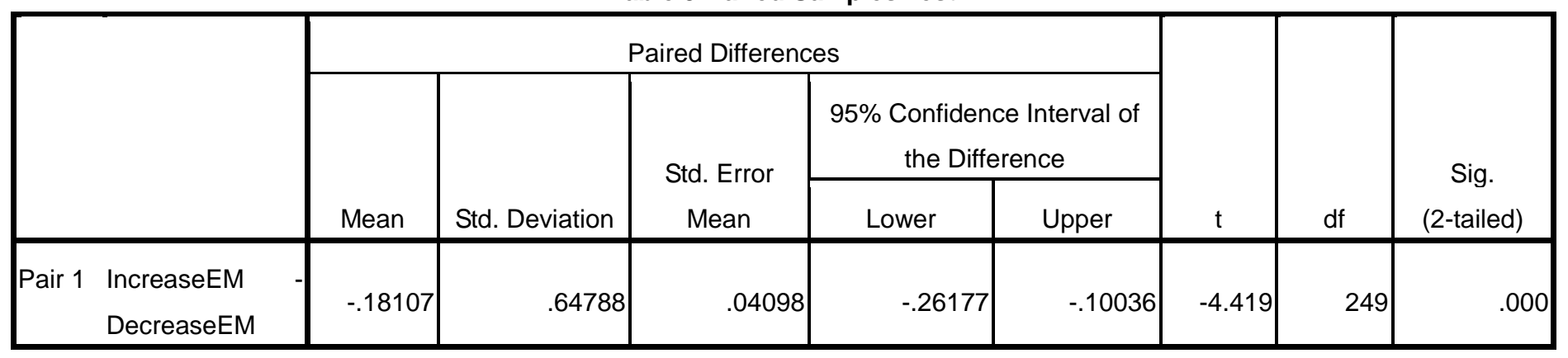

According to Tables 7,8 and 9, we accept our second hypothesis,

Because through the confidence intervals and t-test result have been demonstrated.

Therefore:

There is a significant difference between knowledge ethical earnings management that decrease earnings and earnings management that increase earnings.

Results tests of these hypothesis provided following:

The results indicate type, intent, time, material earnings management Among the groups studied in this paper is judged differently from other studies. So that judge sample students has been that management decrease earnings as more ethical as compared to management increase earnings. judge students is that operating earnings management overall more ethical than accounting earnings management. 
Table 10-Paired Samples Statistics

\begin{tabular}{|rr|r|r|r|r|}
\hline & \multicolumn{1}{|c|}{ Mean } & $\mathrm{N}$ & Std. Deviation & Std. Error Mean \\
\hline Pair 1 & Q8 & 3.40 & 250 & 1.397 & .088 \\
& Q9 & 2.42 & 250 & 1.410 & .089 \\
\hline
\end{tabular}

Table 11-Paired Samples Correlations

\begin{tabular}{|c|c|c|c|c|}
\hline & & $\mathrm{N}$ & Correlation & Sig. \\
\hline Pair 1 & Q8 \& Q9 & 250 & -.035 & .586 \\
\hline
\end{tabular}

Table 12-Paired Samples Test

\begin{tabular}{|c|c|c|c|c|c|c|c|c|}
\hline & \multicolumn{5}{|c|}{ Paired Differences } & \multirow[b]{3}{*}{$\mathrm{t}$} & \multirow[b]{3}{*}{$\mathrm{df}$} & \multirow[b]{3}{*}{ Sig. (2-tailed) } \\
\hline & \multirow[b]{2}{*}{ Mean } & \multirow[b]{2}{*}{ Std. Deviation } & \multirow{2}{*}{$\begin{array}{l}\text { Std. Error } \\
\text { Mean }\end{array}$} & \multicolumn{2}{|c|}{$\begin{array}{c}95 \% \text { Confidence Interval of the } \\
\text { Difference } \\
\end{array}$} & & & \\
\hline & & & & Lower & Upper & & & \\
\hline Pair 1 Q8 - Q9 & .972 & 2.019 & .128 & .721 & 1.223 & 7.613 & 249 & .000 \\
\hline
\end{tabular}

According to Tables 10, 11 and 12, we accept our third hypothesis,

There is a significant differences between knowledge ethical earnings management that affect earnings on a quarterly basis than earnings management that affect earnings on a yearly basis.

\section{Conclusion}

The main purpose of the study was to investigate the ethical perception of senior students concerning different earnings management scenarios. The study measures the differences in ethical perception concerning different groups. These groups consist out of males versus females and accounting versus non-accounting students.

Furthermore, the questionnaire tries to capture five factors that affect student's ethical perception of earnings management scenarios. These factors include; type if action (accounting versus operating manipulation), the direction of the effect on earnings (increase versus decrease earnings manipulation), materiality (low versus high materiality), the period of effect (quarter end versus year end manipulation) and the purpose in mind (company versus individual intent).

The results of the 250 questionnaires indicate that: students judge that:

(1) There is a significant difference between knowledge ethical operating earnings management and accounting earnings management. 
(2) There is a significant difference between knowledge ethical earnings management that decrease earnings and earnings management that increase earnings.

(3) There is a significant difference between knowledge ethical earnings management that affect earnings on a quarterly basis than earnings management that affect earnings on a yearly basis.

Hypothesis 3 states that there is a significant relationship between knowledge ethical earnings management that decrease earnings and earnings management that increase earnings. In the words judge students is base that earnings management that decrease earnings is differently from earnings management that increase earnings. This hypothesis corresponds with the finding of Merchant (1994). However, the results indicate, that students overall judge earnings management that increases earnings as less ethical than earnings management that decreases earnings. A plausible answer for this result may be that students have learned that there is generally a high tolerance for conservatism in financial reporting. Furthermore, students may believe that this conservatism does generally not affect investors' financial decisions as much as boosting earnings and therefore students judge earnings management that decreases earnings as less unethical.

As also mentioned in Merchant (1994), there is a significant disagreement among the respondents for most of the scenarios. This implies that students do not clearly have an understanding about where the line between right and wrong should be drawn. However, it has to be noted that students in this study judge most of the earnings management scenarios as more unethical as compared to Merchant (1994) and Fischer and Rosenzweig (1995). An explanation may be that after the Enron and WorldCom scandals and the credit crisis, respondents' judge earnings management as less ethical than during the period in which Merchant and Fischer and Rosenzweig conducted their research.

Finally, it can be concluded that an important purpose of professional accounting education is to introduce students to the ethics and values of their chosen profession. It should be clearly stated what is wrong and right when preparing budgets and financial statements and reporting earnings. It is advisable for Universities that they provide ethics courses to students during their accounting education. Furthermore, it is important for companies to have strong corporate governance and clearly indicate what is seen as acceptable and what is seen as unacceptable in their accounting practices. Also the current bonus culture in companies should be revised because this is one of the major causes of earnings management.

\section{Limitations}

The study also has a number of limitations. First of all, the total sample of respondents solely consisted of students. Furthermore, the students were all students from the public University of Iran. Different sample consisting out of non students, such as accounting professionals, regulators or the general public may provide different outcomes concerning the different 


\section{Mll Macrothink}

International Journal of Accounting and Financial Reporting

ISSN 2162-3082

2012, Vol. 2, No. 1

earnings management scenarios. The sample mainly consisted out of respondents from Iran, therefore it is likely that respondents from other countries and Asia may give different responses to the earnings management questions.

Secondly, the questionnaire only provides short earnings management scenarios. As mentioned by Merchant (1994) some of the variation in the responses could have been caused by differences in assumptions the students made about some of the unmentioned contextual variables. For example whether the action was within the manager's area of authority and more specific whether or not employees were paid to work overtime (question 5). Therefore it would be possible that if more scenario context would have been provided, the large variances in responses would have been smaller.

Finally, the questionnaire was completely anonymous and responses were handled strictly confidential. The only personal questions asked were gender and fild in this study. However there may be a possibility that some responses were biased due to the fact that some students may have given social desirable or social acceptable answers. There also can be some bias in the order in which the questions are asked.

\section{Reference list}

Arnott, Robert D., 2003. Ethics, earnings, and equity valuation: A crisis of confidence. Journal of Portfolio Management, 8-16.

Bitner, Larry N., CMA, Crawford, C., 2002. Unabashed artful dodgers of the new economy. Strategic Finance, 52-57.

Chung, H., Kallapur, S., 2003. Client importance, nonaudit services, and abnormal accruals. The Accounting Review 78, 931-955.

Elias, Rafik Z., 2002. Determinants of earnings management ethics among accountants. Journal of Business Ethics 40, 33-45.

Elias, Rafik Z., 2004. The impact of corporate ethical values on perceptions of earnings management. Managerial Auditing Journal 19, 84-98.

Fischer, M., Rosenzweig, K., 1995. Attitudes of students and accounting practitioners concerning the ethical acceptability of earnings management. Journal of Business Ethics 14, 433-444

Gaa, J., Dunmore, P., 2007. The ethics of earnings management. Chartered Accountants Journal, 60-62. 
Gowthorpe, C., Amat, O., 2005. Creative accounting: Some ethical issues of macro- and micro-manipulation. Journal of Business Ethics 57, 55-64.

Kaplan, Steven E., 2001. Ethically related judgments by observers of earnings management. Journal of Business Ethics 32, 285-298.

Kaplan, Steven E., 2001. Further evidence on the ethics of managing earnings: An examination of the ethically related judgments of shareholders and non-shareholders. Journal of Accounting and Public Policy 20, 27-44.

Kaplan, Steven E., McElroy, James C., Ravenscroft, Susan P., Shrader, Charles B., 2007. Moral judgment and causal attributions: Consequences of engaging in earnings management. Journal of Business Ethics 74, 149-164.

Lev, B., 2003. Corporate earnings: Facts and fiction. Journal of Economic Perspectives 17, 27-50.

Maher, R., 2008. Ethical decision models and accountant. Chartered Accountants Journal, 4344.

Merchant, Kenneth A., Rockness, J., 1994. The ethics of managing earnings: An empirical investigation. Journal of Accounting and Public Policy 13, 79-94.

Prior, D., Surroca, J., Tribo, Josep A., 2008. Are socially responsible managers really ethical? Exploring the relationship between earnings management and corporate social responsibility. Corporate Governance 16, 160-177.

Rosner, Rebecca L., 2003. Earnings manipulation in failing firms. Contemporary Accounting Research 20, 361-408.

Schepers, Donald H., 2003. Machiavellianism, profit, and the dimensions of ethical judgment: A study of impact. Journal of Business Ethics 42, 339-352.

Soltani, B., 2007. Auditing: An international approach. Prentice Hall, first edition.

Staubus, George J., 2005. Ethics failures in corporate financial reporting. Journal of Business Ethics 57, 5-15. 